\title{
An Ethnobotany of Firewood in Osage Big Moon Peyotism: Practical knowledge, ritual participation, and aesthetic preference
}

\author{
Daniel C. Swan and Lauren M. Simons
}

\section{Research}

\begin{abstract}
This article examines firewood in the context of the modern practice of the Big Moon Peyote Religion by the Osage Indian community of Osage County, in northeastern Oklahoma, U.S.A. The fire and its ritual maintenance is a major component of the all night ceremony of Peyotism. The selection and preparation of the wood used in the ritual fire incorporates botanical knowledge, ceremonial experience, and aesthetic considerations to satisfy a range of preferences and criteria. We also discuss the manners in which firewood, through its ritual use and sacred properties, extends the spiritual benefit and social relationships of Peyotism to the greater Osage community.
\end{abstract}

\section{Introduction}

This article contributes to the broader discussion of firewood in cross-cultural contexts. Scholarly attention to firewood is largely focused on economic and ecological issues associated with the use of firewood and charcoal as principal domestic fuel sources (Biran et al. 2004, Moore 1987:140-153, Stern \& Squires 1984, Taylor 2006, van Kempen et al. 2009). The work reported here contributes to a larger literature on local preferences with regard to the selection of fuel woods. The knowledge of preferred species of wood for use as firewood in both practical and ceremonial contexts is an important element in the traditional knowledge of indigenous people. The selection of certain species for specific purposes is based on a range of criteria and contextual considerations.

Local preferences regarding the selection of wood species for firewood has received a range of attention from scholars including studies designed to compare physical and chemical properties with localized preferences (Chettri \& Sharma 2007, 2009, Ramos 2008). While these studies reveal that preferences and selection criteria for firewood generally correspond closely to the fuel value of various species of wood, a number of additional criteria are involved in the delineation of preferred species including ease of ignition, low spark and smoke levels, and olfactory considerations (Ramos 2008:505).

Among the indigenous people of the subarctic region of Alaska and Western Canada, knowledge of fuel woods, their likely locations, and the ability to make fire under the most severe conditions is a core skill that can make the difference between life and death (Andre 1995:3, Johnson 2008:146). Firewood prefrences among the Teetl'it Gwich'in, in and around the community of Fort McPherson, North West Territories, Canada, also reveals a range of indigenous strategies to manage this critical resource at the household scale, using extremely dry standing dead wood with half-green and green wood to maximize overnight heating (Wishart 2004:170)

\section{Correspondence}

Daniel C. Swan, Sam Noble Museum of Natural History and Department of Anthropology, University of Oklahoma, Norman, Oklahoma, U.S.A. dcswan@ou.edu

Lauren M. Simons, Department of Anthropology, University of Oklahoma, Norman, Oklahoma, U.S.A. simons@ou.edu

Ethnobotany Research \& Applications 12:325-339 (2014)

Published: 23 August 2014 
A closely related area of indigenous knowledge is the selection of different species of wood to smoke food and hides (Andre \& Feehr 2010, Gottesfeld 1994, Holloway \& Alexander 1990). Certain species exhibit chemical properties that imbue the smoke with antibacterial properties, important in the use of smoke as a preservative for fish and meat (Gottesfeld 1994:204, Pennacchio et al. 2010:23). Other species are selected for their respective chemical properties that impart desired flavors in smoked and baked foods and preferred coloration in smoked hides (Gottesfeld 1994:204-205, Holloway \& Alexander 2010:200-22, Pennacchio et al. 2010:4,126,143). Additional studies reveal quire sophisticated sets of preferred species that incorporate a range of practical and aesthetic criteria in the smoking of hides (Goettesfeld 1994:204205, Holloway \& Alexander 1990:220-21). Evidence of species preference in ceremonial contexts is supported by archaeological analysis of Mayan sites and contemporary ritual practice (Moerhart et al. 2005.) In this report we examine the criteria employed by Osage Peyotists in their identification of preferred species of firewood for use during religious services.

In 1937, Richard Evans Schultes published "Peyote and other plants used in the peyote ceremony," a seminal discussion of the various botanicals associated with the $20^{\text {th }}$ century practice of the Peyote Religion. Although the article is largely devoted to the ethnobotany of the peyote plant (Lophophora williamsii (Lem. ex Salm-Dyck) J.M.Coult.), it does provide a general inventory of the botanicals used in the ceremony as documented among Oklahoma tribal communities in the 1930s by Schultes and his colleague Weston La Barre (Schultes 1937:138). Shultes produced a general ethonobotany of the Kiowa-Comanche or "Little Moon" form of the Peyote Religion (La Barre 1989:43-56, Mooney 1897:129-130, Slotkin 1956:22-27, Stewart 1987:53-67) that developed in Oklahoma in the late $19^{\text {th }}$ century and subsequently diffused throughout the continent (La Barre 1989:109-123, Slotkin 1956:28-47, Stewart 1987:97-127, 148-209). The authors are working to produce a compliment to Schultes' research based on extensive interaction with Osage Peyotists, the only current practitioners of the parallel and related "Big Moon" form of the Peyote Religion (Bailey \& Swan 2004, Swan 1990,1998,1999). Here we address a botanical element of Peyotism that is arguably second only to peyote ( $L$. williamsii) in its importance to the practice of the religion. That element is firewood, a critical element in Native American religious practice and belief.
The ritual fire (Figure 1), called hpe'ce in Osage (Morrell $1986: 1 \mathrm{~A}$ ), is a central element in all peyote ceremonies, and its form and maintenance by a ceremonial official, the Fireman, has been consistently stressed in published accounts of the religion from its earliest description (Mooney 1892) to more recent assessments (Maroukis 2004). As an all night ceremony the fire has both practical and spiritual properties in the Peyote Religion. The fire provides the major source of light and heat and also serves as a central focus of the worshippers as they meditate and pray during the night. In one of the first reports on the Peyote Religion, James Mooney (1896:10) captures the importance of the fire in his comments:

"The psychological effect is perhaps the most interesting, as it is certainly the most wonderful, phenomenon in connection with the plant. Much of this is undoubtedly due to the ceremonial accompaniments of prayer and song, the sound of the drum and rattle, and the glare of the fire."

Mooney was among the first to note the importance of the ceremonial setting on the religious experiences of Peyotists. In his testimony before a sub-committee of the House Committee on Indian Affairs, Francis La Flesche (U.S. Congress 1918:115) reports a similar effect of the fire on the attendees of an Osage peyote service. He commented that the worshippers spent much of the service gazing at a briskly burning fire, an experience that La Flesche remembered from his youth when he and his friends would build a fire and then gaze at the glowing coals to identify patterns and images. Thus the fire is not only inimportant for both the light and heat that it generates but

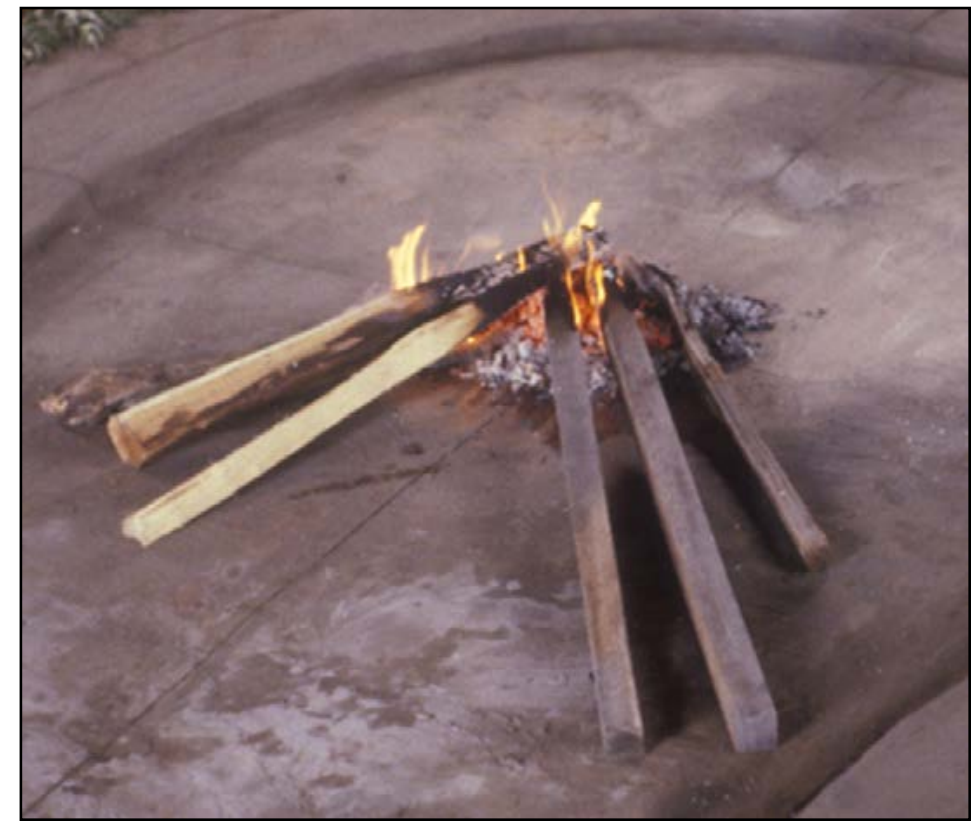

Figure 1. Fire, hpe'ce, at Morrell Church, Hominy, Oklahoma, U.S.A., ca. 1989. Photograph by Daniel C Swan, courtesy of Preston Morrell. 


\section{Swan \& Simons - An Ethnobotany of Firewood in Osage Big Moon Peyotism: 327 Practical knowledge, ritual participation, and aesthetic preference}

also for its ability to contribute to the mood of the ceremonial setting and the experiences of the worshippers. While the difference between a wood fire as a contemplative focal point for collective Native American Church worship and the shared experience of a rain of falling firecrackers is great, an analog is found in the patum festival of Catalonia in which a system of aggressive communion is employed to achieve the explicit goal of creating a sense of "oneness." In both ceremonial traditions, the participants share powerful performance and sensory experiences focused on fire to achieve a "collective effervescence" (Noyes 2003:120).

Although there is no evidence that the species used as firewood in peyote ceremonies has ever been religiously prescribed, there are clear sets of preferences that reflect both practical and ritual considerations. Schultes (1937: 140) identified two important criteria for peyote firewood, noting that it should be slow-burning with little or no pops and sparks. The latter concern is paramount (Hill 1971:13, Jordan 2008:169, La Barre 1989:77, Mc Allester 1949:21) given that worshippers are generally seated on rugs and pieces of canvas spread on the ground in fairly close proximity to the fire. Sparks and smoldering embers also pose a threat to the cushions, pillows, blankets, and shawls that are employed throughout the all-night service. Despite the obvious dangers, sparks and flying embers are quite disruptive of the religious setting as they must be hastily located and extinguished. The fires in peyote ceremonies are built "crib" fashion in a V-shape with the opening to the east (doorway) and eight or more pieces of wood stacked to over 1 foot tall (Aberle 1991:129, Mooney 1897:331, Slotkin 1952:586, 1956:72.). Wood that "pops," or in actuality explodes, causes this meticulously and aesthetically arranged fire to fall into chaos.

Additional criteria that receive mention in the literature concern the amount of smoke produced by the fire (Mc Allester 1949:21) and the ease with which the firewood can be split into the preferred dimensions of approximately $100-120 \mathrm{~cm}$ in length and $6-10 \mathrm{~cm}$ in breadth and width (Maroukis 2004:186, Slotkin 1952:586). The amount of smoke generated by the fire is influenced by many factors including the manner in which the fire is "built" and the degree of "seasoning" or moisture content in the wood. An additional step taken in the preparation of peyote firewood is the removal of the bark - a practice of extreme importance in reducing pops, sparks, and smoke.

Schultes' (1937:140) list of preferred or acceptable woods among Little Moon Peyotists in Oklahoma identified blackjack oak (Quercus marilandica (L.) Münchh.) as a favorite with red oak (Quercus rubra L.), hackberry (Celtis occidentalis L.), redbud (Cercis canadensis L.), box-elder (Acer negundo L.), and cottonwood (Populus deltoides Bartr. et $x$ Marshall) providing suitable substitutes. Additional sources on Peyotism and Native American ethnobotany (Hill 1971, Jordan 2008:169-17, La Barre 1989:77, Ves- tal \& Schultes 1939:20-21, 41) isolate a general pattern of preferred species in Oklahoma, with slippery elm (UImus rubra Muhl.) and red oak (Quercus shumardii Buckley) identified as ideal winter woods and box-elder ( $A$. negundo) and redbud (C. canadensis), as good woods for summer based on their ability to produce large amounts of light with little heat. White ash (Fraxinus americana L.) and cottonwood ( $P$. deltoides) were also identified as acceptable, general-purpose woods, a reminder that availability is often a major factor in selection.

\section{Big Moon Peyotism}

In general the Big Moon form of Peyotism holds much in common with its Little Moon counterpart in terms of theology and ceremony and generally represents an elaboration of ritual practice and the ceremonial division of labor (Bailey \& Swan 2004:110-111, Swan 1999:30). Specific examples of this Big Moon elaboration of the general Little Moon form include a ritual of longer duration, a doubling of the number of ceremonial officials, and an expanded set of rules to govern the movement of people and ritual instruments during religious services.

Big Moon Peyotism originated among the Caddo and was refined and disseminated by John Wilson in the early 1890's (La Barre 1989:75-76,151-161, Petrullo 1975:81-86, Speck 1933:541-543, Stewart 1987:91, Swan 1990:157-166). Wilson introduced the Big Moon form of Peyotism among several communities, including the Wichita, Delaware, Quapaw, and Osage, although it was among the latter group that he established its greatest following. Introduced among the Osage in 1897-98, Big Moon Peyotism rapidly gained attention and converts. The Osage have consistently practiced Big Moon Peyotism since its inception in the late $19^{\text {th }}$ century (Swan $1990,1998)$ and are the only current practitioners of the form as of 2013. Throughout this history it is clear that Osage peyote congregations were comprised of individuals of diverse tribal and ethnic heritages. While Swan was active among Osage Peyotists in Hominy, Oklahoma, U.S.A., it was common for members of the Caddo, Quapaw, Eastern Shawnee, and individuals from neighboring tribal communities to be regular participants in Osagesponsored Big Moon Peyote services. Jason Jackson (2005:174) identifies a similar situation in his isolation of corporate and congregational levels of participation at Woodland Ceremonial grounds in Oklahoma.

John Wilson attributed his innovations, including the enlarged ceremonial altar, or "moon," and its associated markings, to a series of divine revelations that he received during a period of ritual seclusion (Speck 1933:541-43). Big Moon altars (Figure 2) are constructed of a durable material, formerly pond clay and later cement, and are often covered by an eight- or ten-sided, wooden frame church house (Figure 3). These innovations significantly contrast with the use of a temporary earthen altar and 


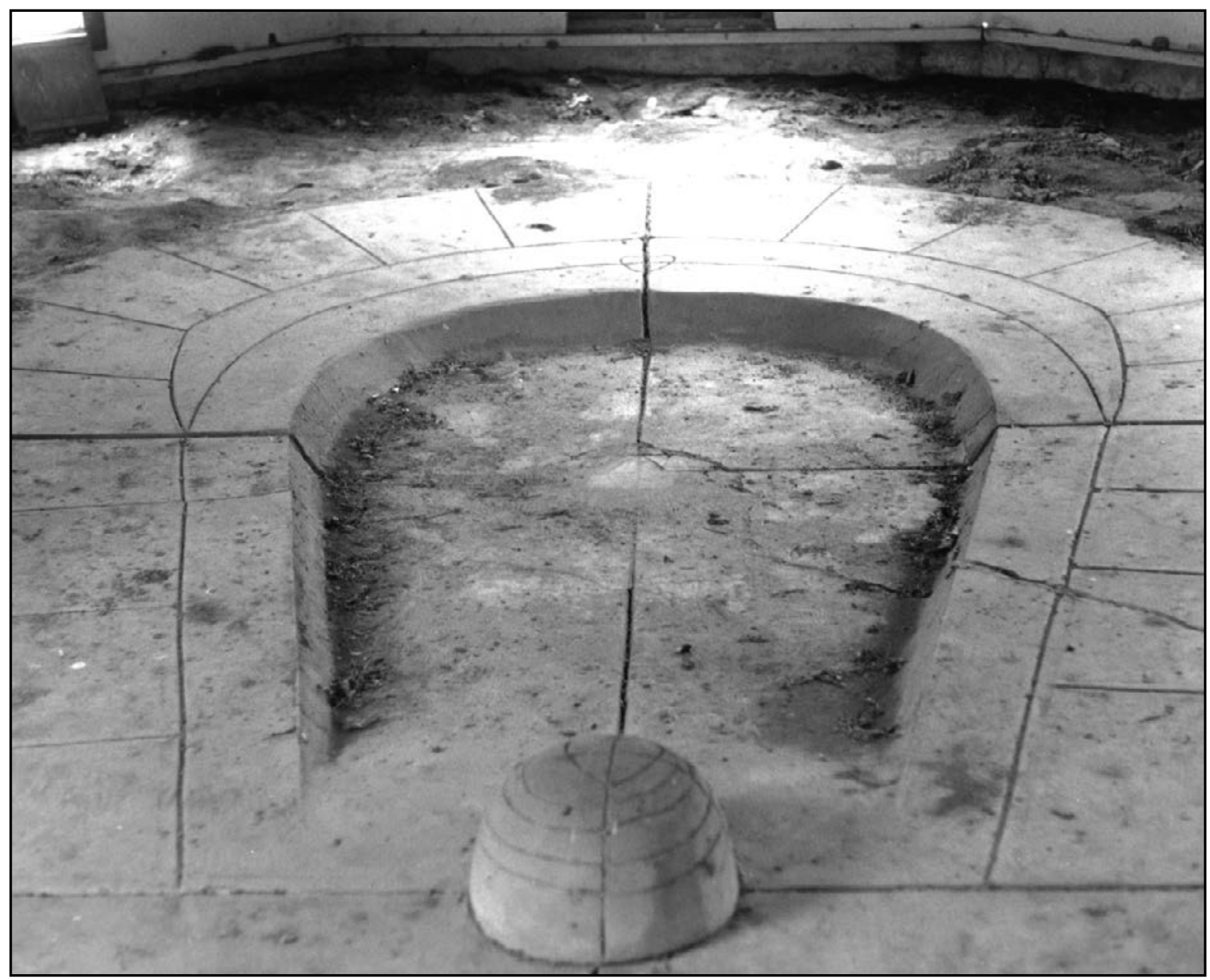

Figure 2. Big Moon altar, White Horn Church, Sycamore Creek, Osage County, Oklahoma, U.S. A., ca. 1992. Photograph by Daniel C. Swan, courtesy of Dudley White Horn.

canvas tipi in the majority of Little Moon ceremonies. The importance of firewood in Osage Peyotism gains architectural expression in the close association of a substantial woodshed with each Big Moon church house.

\section{Research Setting and Methodology}

The research design for our study was non-experimental and qualitative in nature. The central objective of the research reported in this article was the comprehensive analysis of firewood as employed in Big Moon Peyote ceremonialism. Our research incorporates a synthesis of previous research and longitudinal fieldwork among Osage Big Moon Peyotists. The original data presented in this article was gained during Swan's residence in the Osage community between 1984 and 1990 and through his ongoing relationships with Osage peyote congregations over the past thirty years. The principle method of data collection was extensive participant observation that included numerous excursions to harvest and process fire- wood for use in Osage peyote services. Additional insight regarding the ritual fires of Osage Peyotism was gained through attendance at ceremonies held at several Osage Big Moon churches in Osage County. These experiences were significantly amplified through extended, semi-structured, and free-form ethnographic interviews with members and leaders of the religion in the Osage community (Bernard 2011:156, 256). An additional source in Swan's understanding of many aspects of Osage Peyotism was the on-going discourse among Osage Peyotists, particularly young male adults, during their efforts to gain ceremonial knowledge and ritual experience.

Parallel associations among Little Moon Peyote congregations in Hochunk, Kiowa, Navajo, and other native communities provide Swan with a broader comparative context for the current discussion. Simon contributed to the bibliographic review of the relevant anthropological and botanical literature regarding the species discussed in this paper. She also analyzed species distribution data for 


\section{Swan \& Simons - An Ethnobotany of Firewood in Osage Big Moon Peyotism: 329 Practical knowledge, ritual participation, and aesthetic preference}

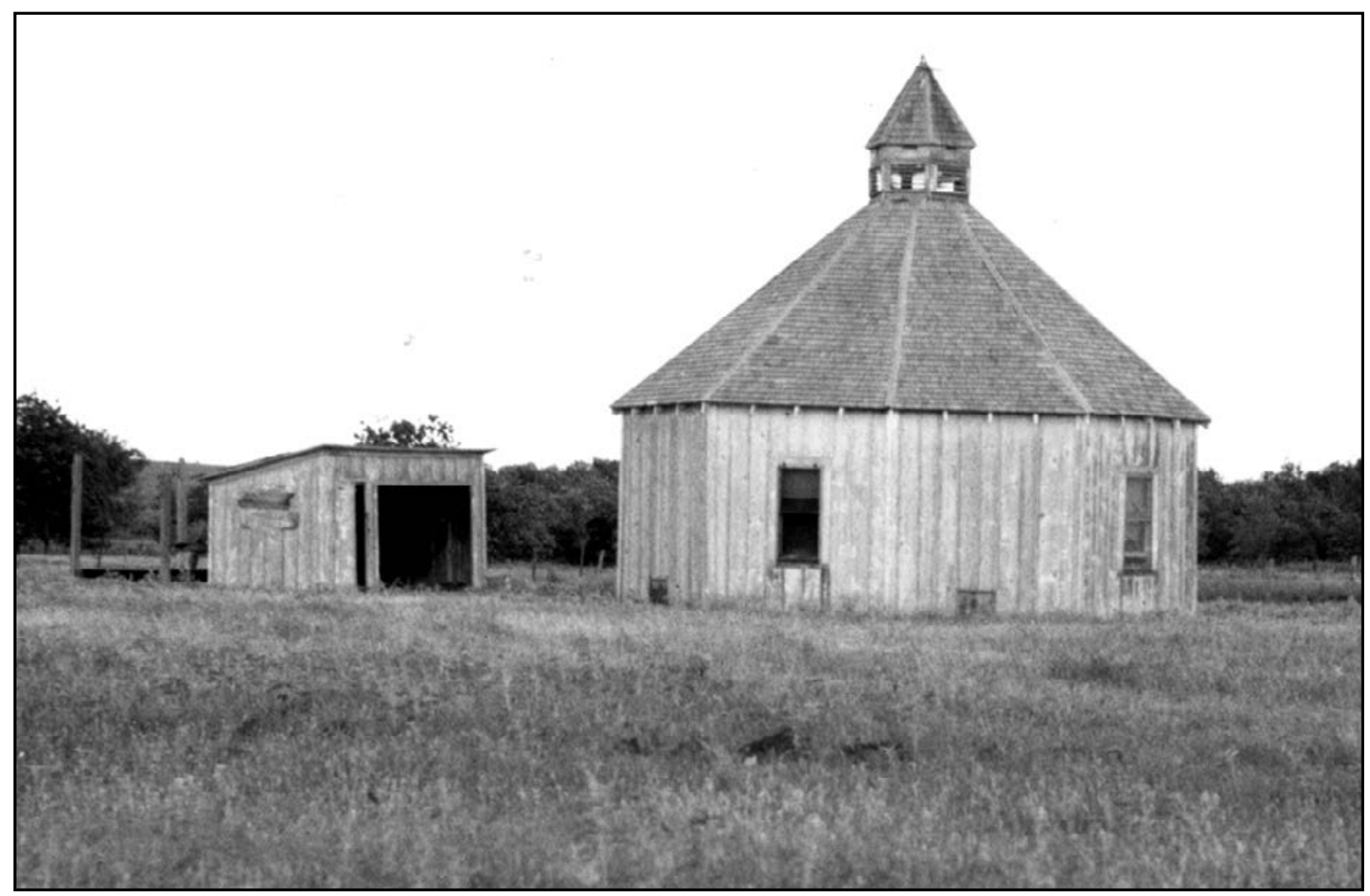

Figure 3. Osage church house with woodshed (left), Hominy, Oklahoma, U.S.A., ca. 1955. Courtesy Archives, University of Colorado at Boulder Libraries, Omer Stewart Collection, Box 63, Envelope 3.

both present day Osage County, Oklahoma, and historical territorial domains of the Osage.

\section{Results}

One of the more important aspects of our research to document the ethnobotany of Osage Big Moon Peyotism involved the identification of dynamic relationships between humans and plants. In this report we focus on the species of wood that provide the means to produce a critical ceremonial element in Peyotism: the ritual fire. Acknowledged as an ancient life force possessing great spiritual significance, the fire in Osage Peyotism is embodied, gendered and addressed as a senior relative, Grandfather. The view of the fire as a spiritual intermediary between humankind and the Creator is well evidenced in the concept of "divine witness" as described among the Shawnee (Howard 1981:179-182) and Yuchi (Jackson 2003:73).

The overwhelming majority of the fires used in the Osage Big Moon Peyote services attended by Swan were lit via the flint and steel method, viewed as a direct link to the manner in which previous generations of Osage people produced fire. This type of fire is referred to by Swan's Osage mentors as a "rock fire." A fire created in this manner is also a surrogate for the sun, the supreme giver of life in Osage cosmology. The sacred nature of the fire is explained by Preston Morrell (1994:044A):

"That fire built for peyote ways - they use it properly, orderly. God gave us an order that we have to follow. It's towards God. You pray for all that. They try to keep it just as holy as possible. They watch it carefully."

Among the Osage there are three "firemen," hpe'ce l'hta in Osage (Morrell 1986:1B), whose ranked positions are referred to by descending number with the First Fireman possessing considerable authority and responsibility in Osage peyote ceremonies (Maker 1968:2-3, Morrell 1986:1B, Swan 1990:280). Central among these responsibilities is that of securing an ample supply of firewood to support a Big Moon Peyote ceremony (Maker 1968:3: Morrell 1994:1A). Osage firemen and additional younger, male relatives, commonly under the leadership of the First Fireman, spend a significant amount of time and effort to procure and prepare sufficient quantities of wood to support an active Osage Peyote Church. All active churches strive to maintain a ready supply of firewood to support both a regular schedule of religious services and unanticipated circumstances. Among the Osage it is common for active churches to sponsor a minimum of a religious service in the spring and fall of each year with additional services held for funerals, memorial meetings, weddings, 
graduations, and numerous additional purposes. Beyond both regular and special services, an active church should be ready to conduct an "emergency" peyote ceremony to meet immediate requests for spiritual and physical healing.

Osage firemen are well experienced in the procurement of peyote firewood and possess a broad knowledge of native woods and their identification by foliage, bark, blossoms, and fruit. Individuals who cut peyote wood accumulate considerable equipment to achieve their tasks, including at least one chain saw, fuel, maintenance supplies, mauls, wedges, splitting adzes, axes, chains, ropes, and other hand tools (Figure 4). A pick-up truck is preferred to facilitate access to remote rural areas and means to transport cut logs for further processing. Peyotists invest considerable energy and time to locate, cut, and process firewood for use in religious services.

Wood used in the ceremonial fires of Osage Peyotism is generally shorter in length than that used in Little Moon ceremonies. This is largely due to the confines of the re- cessed fireplaces of the concrete Big Moon altars. These "sticks," as referred to by members, are obtained by cutting a segment of a tree to the appropriate length, removal of all bark, and then splitting the log into the desired size, approximately $75-90 \mathrm{~cm}$ in length and $5-8 \mathrm{~cm}$ in width and height (Figure 5). Logs of $60 \mathrm{~cm}$ in diameter and larger are often harvested with segments (sticks) taken off in concentric rings.

The wood is then stacked to dry for varying lengths of time, ranging from a few months to one year depending on species, storage conditions, and the ambient environment. As discussed previously the proper seasoning of the wood is a critical factor in the success of its use as firewood in peyote meetings. Osage firemen also exhibited great interest when "standing dead wood" was encountered during the quest for peyote wood. This term was applied to trees of a desired species that had died but were still standing in an upright position. If the wood is harvested prior to the ravages of rot and insects it is often ready to burn with little or no additional seasoning required. Fallen deadwood is generally avoided, and the general pref-

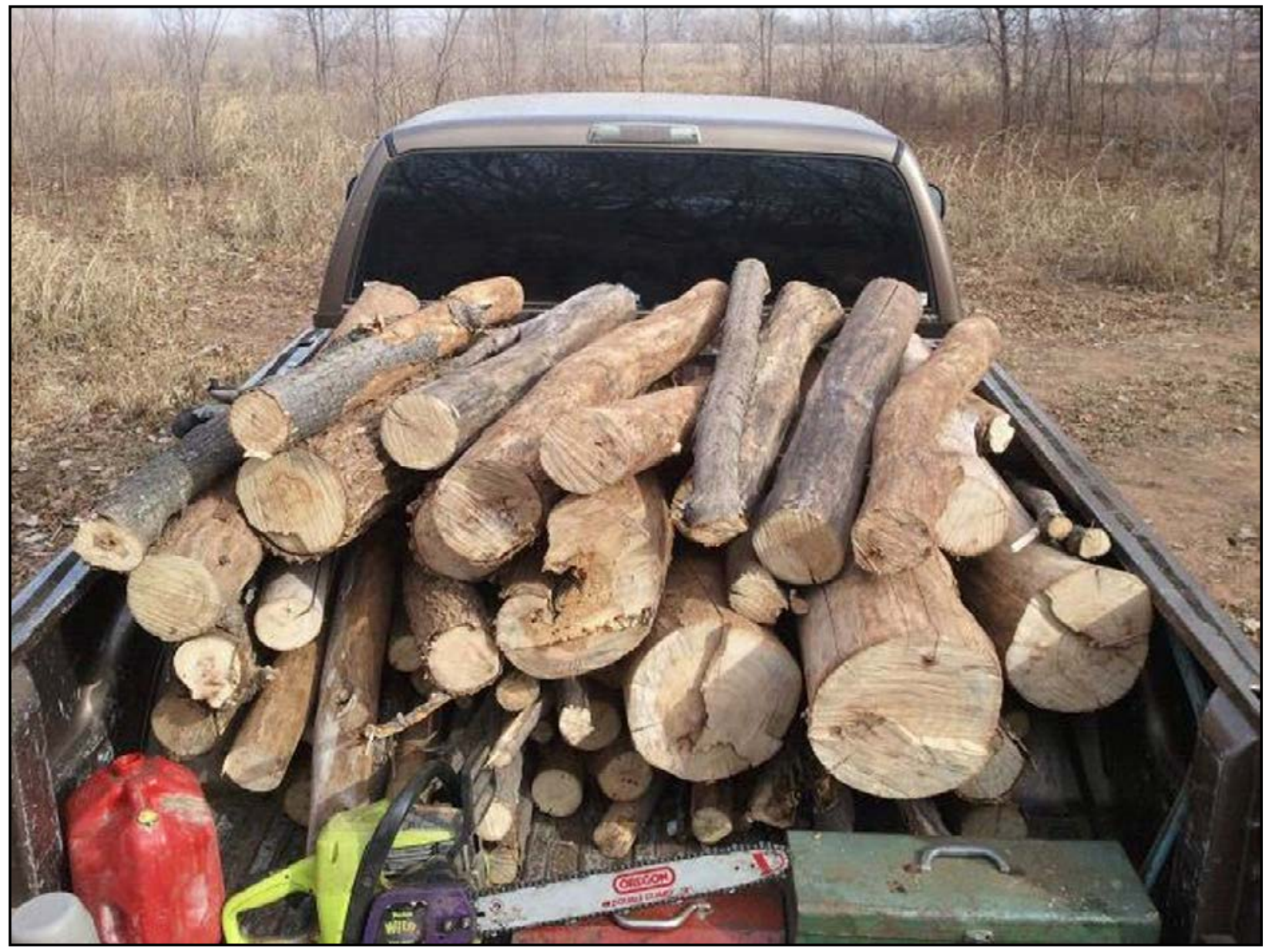

Figure 4. Cut and partially debarked logs and tools, Oklahoma, U.S.A. 2012. Courtesy of Stephen Littlecook. 
Swan \& Simons - An Ethnobotany of Firewood in Osage Big Moon Peyotism: 331 Practical knowledge, ritual participation, and aesthetic preference

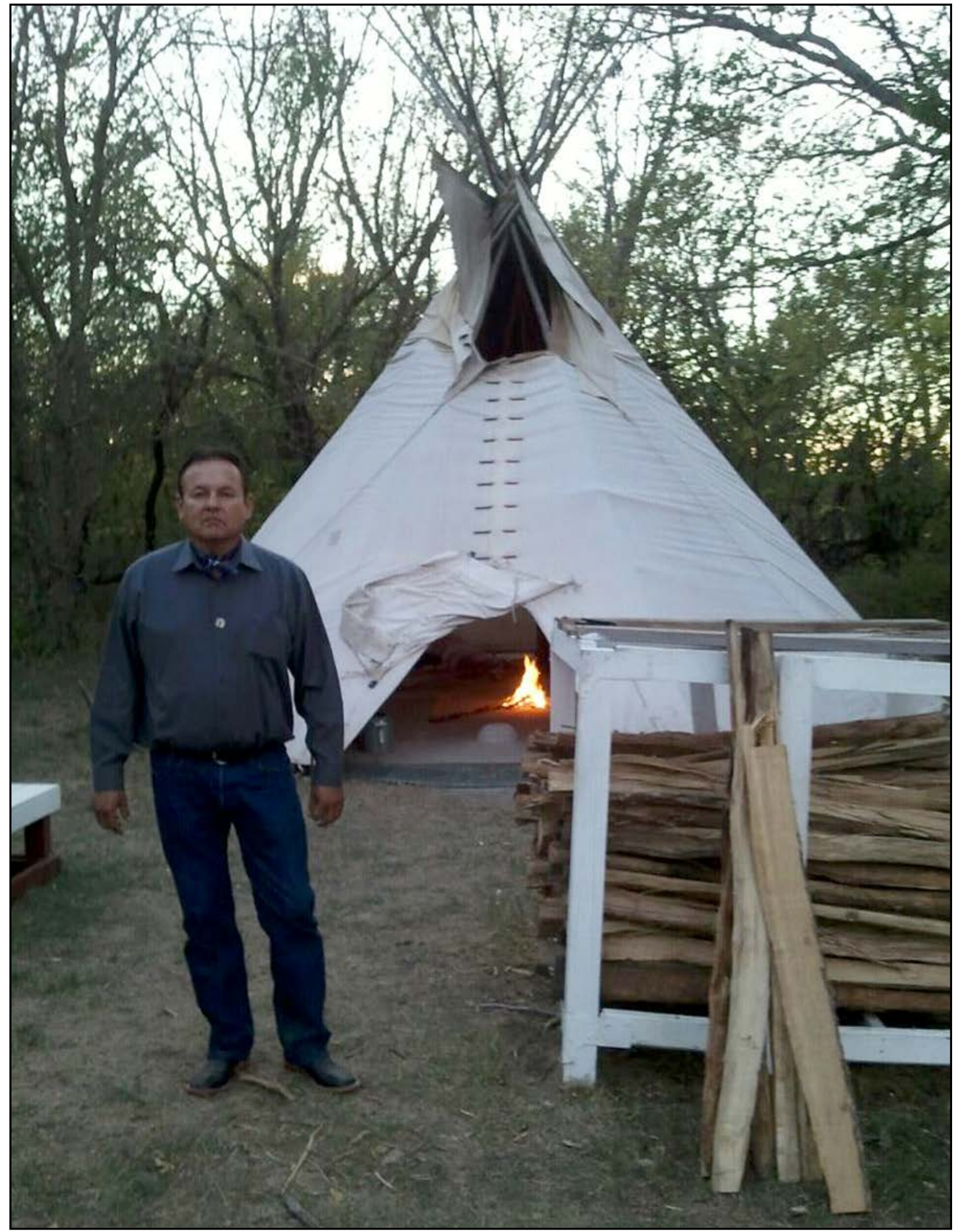

Figure 5. Andrew Gray with split Peyote firewood, Jennie Gray Church, Pawhuska, Oklahoma, U.S.A. 2012. Photo by Maggie Gray, courtesy of Andrew Gray. 
erence is for live, favored species, cut, prepared, and seasoned specifically as "peyote firewood."

The amount of wood used during a religious service is highly variable, depending on a range of factors beyond environmental conditions, including the particular airflow in each church house, or tipi as used at one modern Osage fireplace, and the propensities and preferences of the Roadmen who direct the religious services and the firemen who maintain the ritual fires. Swan's experience would indicate that $60-80$ sticks provide a general average of the amount of wood consumed in the ceremonial fire of an Osage Big Moon ceremony. Services during the winter generally require considerably more, between $100-120$ sticks, and summer meetings might consume 60 sticks or fewer. Swan also observed meetings where exceptional amounts, both low and high, of wood were consumed in the conduct of an Osage peyote meeting. The two most important variables in the level of wood consumption are seasonality and the individual practices of the firemen. Based on his experiences Swan would suggest that Osage Peyotists generally prefer a brisk, fastburning fire that produces a great amount of light and themselves by placing their hands toward the fire and then patting their body.

Swan also isolated aesthetic considerations with reference to peyote fires and the woods that fuel them. The flames and coals produced by certain species are favored by Osage Peyotists based on a set of visual preferences. In numeric order the three firemen in Osage Big Moon services take a turn adding wood to the fire and sweeping the altar clean of embers and ashes in a highly prescribed manner (Maker 1968:11-12, Morrell 1986:1A). This activity is ideally undertaken four times during one circuit of the drum around the ceremonial circle. Firemen rotate upon the completion of a round. In Osage ceremonies this activity is accomplished with the aid of a set of Fireman's tools that consists of a house broom, a whiskbroom, a dustpan, a watering can, a single hickory (Carya ovata (Mill.) K.Koch) pole, and two dogwood (Cornus drummondii C.A.Mey.) sticks with the outer bark removed (Figure $6)$.

Considerable experience is required to perform the duties of the Fireman in an expedient and productive mancoals. These preferences may relate to the use of a wooden frame church house as the ritual setting. Church houses contain voluminous spaces measuring 6-12 $\mathrm{m}$ across and 6-10 $\mathrm{m}$ tall and require a large, active fire to provide the preferred levels of light and heat.

The ritual fire in Osage Peyotism is the major source of light and warmth in the ceremonial setting and also provides a focal point for the attention of participants during the religious service (U.S. Congress, House Committee on Indian Affairs 1918:115, Morrell 1986:1B). The continuous maintenance of the fire is a significant element in the ritual action of Big Moon Peyote ceremonialism. At numerous points throughout the service the fire is used as a source of purification and a conveyor of God's blessings. Morrell described the smoke from prayer cigarettes, tobacco rolled in a cornhusk wrapper, lit from the ceremonial fire as "a telephone to God, a direct line" (1986:1B). At the Morrell Church, attended frequently by Swan, the ceremony paused briefly after midnight so that the parishioners might interact with the fire on a personal level, with individuals often moving into the altar area to pray and bless

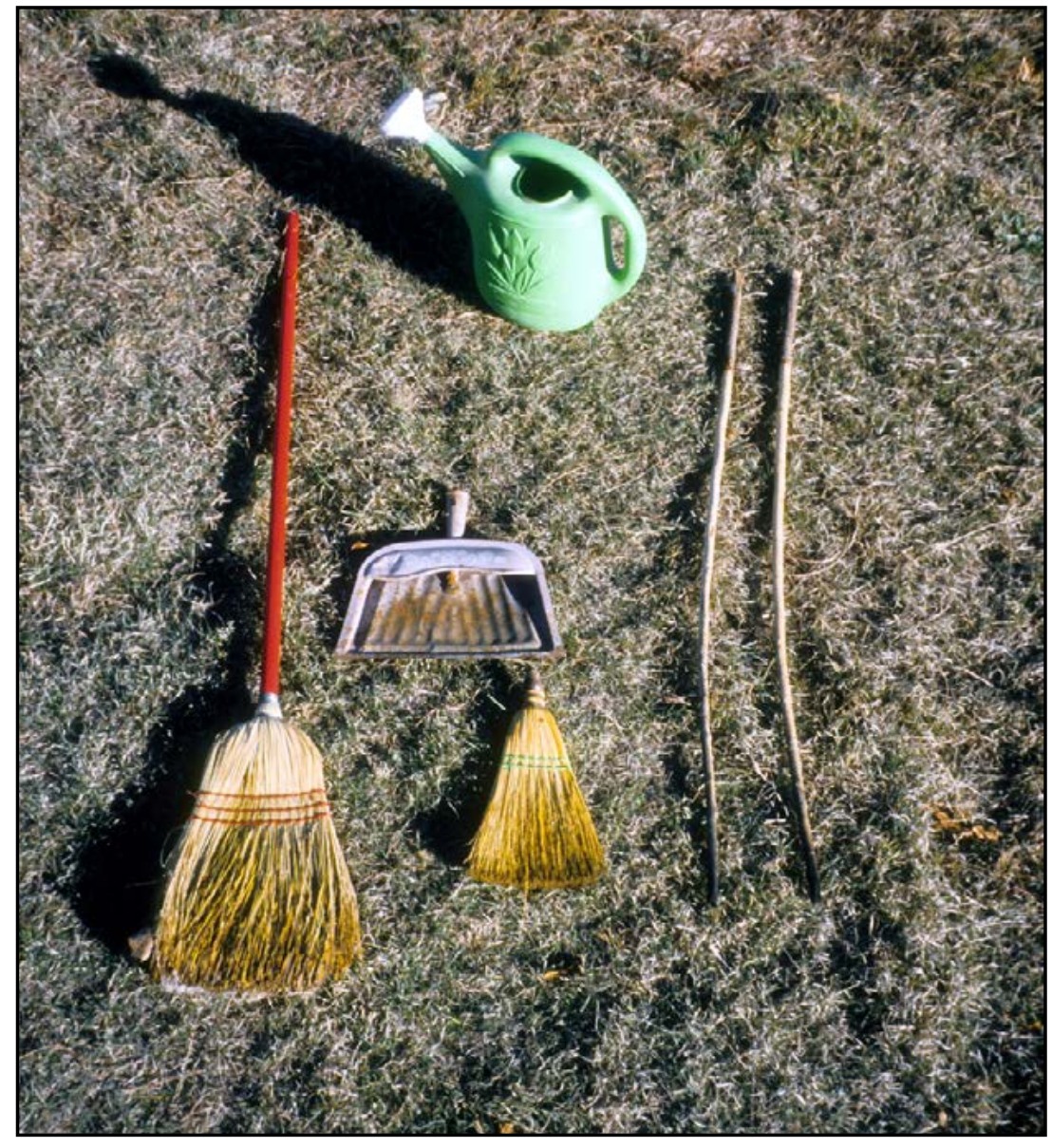

Figure 6. Fireman's tools, Morrell Church, Hominy, Oklahoma, U.S.A., ca. 1994 Photograph by Daniel C. Swan, courtesy of Preston Morrell. 


\section{Swan \& Simons - An Ethnobotany of Firewood in Osage Big Moon Peyotism: 333 Practical knowledge, ritual participation, and aesthetic preference}

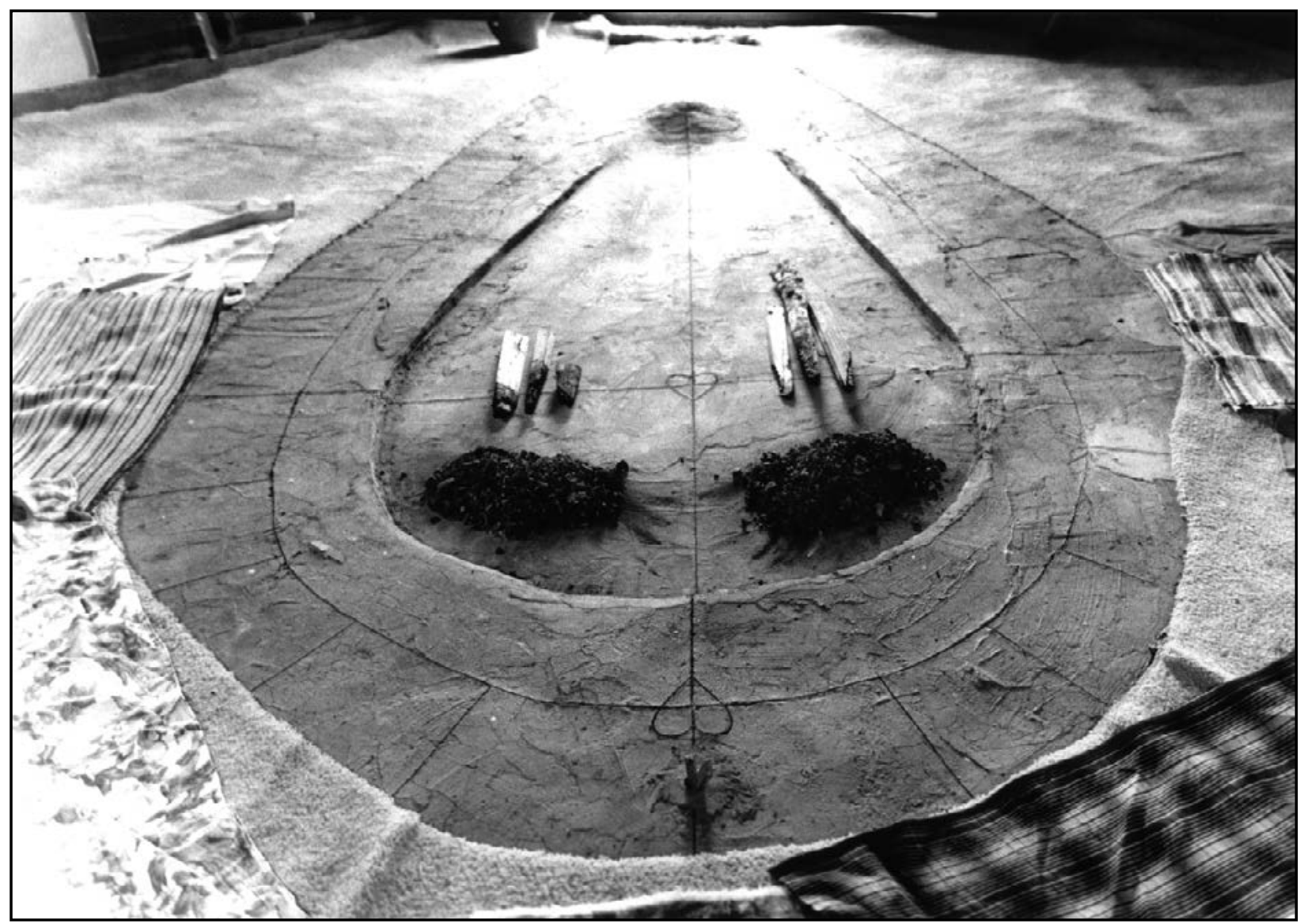

Figure 7. Osage Big Moon altar with coal mounds (post ceremony), Morrell Church, Hominy, Oklahoma, U.S.A., ca.1990. Photograph by Daniel C. Swan, courtesy of Preston Morrell.

ner (Maker 1968:2-3). Using these tools the firemen pull the burning wood back a few feet where it is restacked and fanned into flame. The accumulated coals are then divided and pushed forward with the hickory staff. The house broom is then used to sweep these coals into two neat piles in the north and south quadrants of the western end of the Big Moon altar (Figure 7). The preference is for these piles of coals to continue to burn without flame or smoke with constant re-working to knock the ash off the coals to prolong this effect. The entire altar is then watered with the sprinkling can and swept clean with the house broom. This continuous process of replenishment requires a robust fire to insure the steady supply of long lasting coals. The undisputed favorite for this purpose is red oak (Q. shumardii) with slippery elm (U. rubra) and white ash (Fraxinus americana L.) acceptable substitutes. Fires from these woods produce abundant amounts of well-defined, cube-shaped coals that exhibit long-lasting, intense surface combustion.

An additional aesthetic consideration was reported to Swan by Morrell regarding the use of redbud (C. canadensis) wood as fuel for peyote ceremonial fires (Morrell, per- sonal communication). Redbud (C. canadensis) is identified in the literature as an ideal peyote wood for summer based on its ability to produce large amounts of light with little heat or sparks (Hill 1971:13, La Barre 1989:77). Morrell told Swan that his father liked to use redbud (C. canadensis) in the Spring of the year based on its propensity to produce a bright, pinkish flame, symbolic of the Spring and new year (Morrell, personal communication). We interpret this as an extension of the dawn symbolism that is prominent in Peyotism, representative of the new day, a day entered into in holy order. Dawn is generally celebrated in Little Moon Peyote meetings with a morning water ceremony and a ritual breakfast (La Barre 1989:90-92), and dawn symbolism is well evidenced in McAllester's (1949:32-33) analysis of peyote song texts. The pink hue of scissortail feathers, prized for fans and strongly associated with the morning portion of the religious service, provides an additional example of the diversity of dawn symbolism in the Peyote Religion.

Anthony Davis, a Pawnee leader in the Native American Church, related the following to Anderson (1996:60) regarding the selection of peyote firewood: 
"Each Fire chief knows the particular type of wood to burn to produce different ashes, coals and colors. Some may even mix the types of wood to produce a variety of colors at once."

His reference to multi-colored flames in peyote fires expands on Morrell's experience and suggests a need for continued research on aesthetic considerations in association with Native American ethnobotany. The one time that Swan assisted in the preparation and use of redbud (C. canadensis) in an Osage peyote service it did indeed produce a bright pink flame, and it remains for further research to determine its exact causality. The wood displayed a twisted grain making it difficult to split, and once split it took an exceptionally long time to properly cure. The batch used in this instance was actually under-cured and omitted a fair amount of smoke and an oily residue as it burned. Experienced firemen at this Church who had no prior experience with redbud (C. canadensis) found it to be less than ideal largely based on the total lack of coal production, causing the maintenance of the coal mounds to be extremely challenging if not impossible. This may represent a situation similar to that reported above by Davis, in which the use of multiple species is necessary to satisfy a divergent set of practical and aesthetic preferences.

The fire also provides the means through which the various ritual components of a complete Big Moon Peyote service gain physical and spiritual connection. Ideally a minimum of three days are required to conduct a Big Moon Peyote ceremony, beginning with a sweat lodge ceremony at dawn on the first day followed by the ceremonial assembly of the ritual instruments and preparation of the peyote sacrament at dawn on the second day, with the actual ceremony initiating on the evening of the second day. The all-night ceremony concludes at noon on the third day with a large dinner that is attended by participants in the ceremony, their families, and members of the larger Osage community. Osage Peyotists generally start the initial fire via the flint and steel method to serve the needs of the sweat lodge ceremony and then carry this fire through to the concluding meal on Sunday. Coals from this fire are moved from location to location to accommodate the sequence of ceremonial events associated with Big Moon Peyotism. A special set of rules and protocols governing its use and treatment are invoked for a cook fire started with coals from the peyote ceremonial fire (Morrell 1994:2A).
The ritual fire of Osage peyote ceremonialism gains further impact in the larger Osage community through a number of mechanisms. Coals from the ritual fire are often collected at the conclusion of the ceremony and placed into a cast iron Dutch oven (Figure 8). These coals are then transported to the home of a community member to conduct a cedar ceremony in which the dried needles of the red cedar (Juniperus virginiana L.) are burned atop the coals carried in the Dutch oven to produce a vibrant smoke incense. This smoke and fragrance are used to bless and cleanse a house following the death of a family member or in instances of physical and spiritual unrest. The benefits are mutually derived from the inherent powers of the cedar and the sacred nature of coals from the peyote ceremonial fire (Jackson 2013:103,115-116, Moerman 1998:291).

An additional extension of the Big Moon Peyote ceremony is found in the practice of collecting the accumulated ashes from the recently extinguished ceremonial fire. These are then sifted and cleaned for presentation to an elder female who will use them to make hominy corn (Zea mays L.), leaching lye from the hard wood ashes with fresh rain water (Gilmore 1991:15, Onion 1964:65). On several occasions Swan witnessed requests for these ashes from community members who often inquired as to the species of wood used during the ceremony. Hominy prepared in this manner is considered special and reserved for important occasions. Gifts of this valued product are often made to the Roadman whose church supplied the ash and to other community elders.

\section{Discussion}

Swan's long-term interaction with a congregation of Osage Peyotists in Hominy, Oklahoma, U.S.A., provides sufficient data to isolate a small set of species (USDA 2009) that comprised the majority of woods employed as ceremonial firewood at this church between 1984 and 1990 (Table 1). All of these species are readily abundant in the diverse habitats of Osage County, Oklahoma, U.S.A., the former Reservation of the Osage Nation from 1876-1906 (Oklahoma Biological Survey 2013). The authors are unaware of any current activity or discussion among Osage Peyotists regarding the management of preferred species of ceremonial firewood. Current demand appears to

Table 1. Primary species used as firewood at Morrell Big Moon Church, Oklahoma, U.S.A. 1984-1990.

\begin{tabular}{|l|l|l|}
\hline Scientific Name & Common Name & Osage Name \\
\hline Cercis canadensis L. & red bud & Zhǒ shabe (La Flesche 1932:226) \\
\hline Fraxinus americana L. & ash / white ash & Zhô-gthé-çe-hiu (La Flesche 1932:225) \\
\hline Populus deltoides Bartr. ex Marshall & cottonwood & Žáąk?a (Quintero 2009: 257) \\
\hline Quercus shumardii Buckley & red oak & Hpisu'hu (Quintero 2009:81) \\
\hline Ulmus rubra Muhl. & red elm & Hin-dse ni-tsi-stue (La Flesche 1932:61) \\
\hline
\end{tabular}




\section{Swan \& Simons - An Ethnobotany of Firewood in Osage Big Moon Peyotism: 335 Practical knowledge, ritual participation, and aesthetic preference}

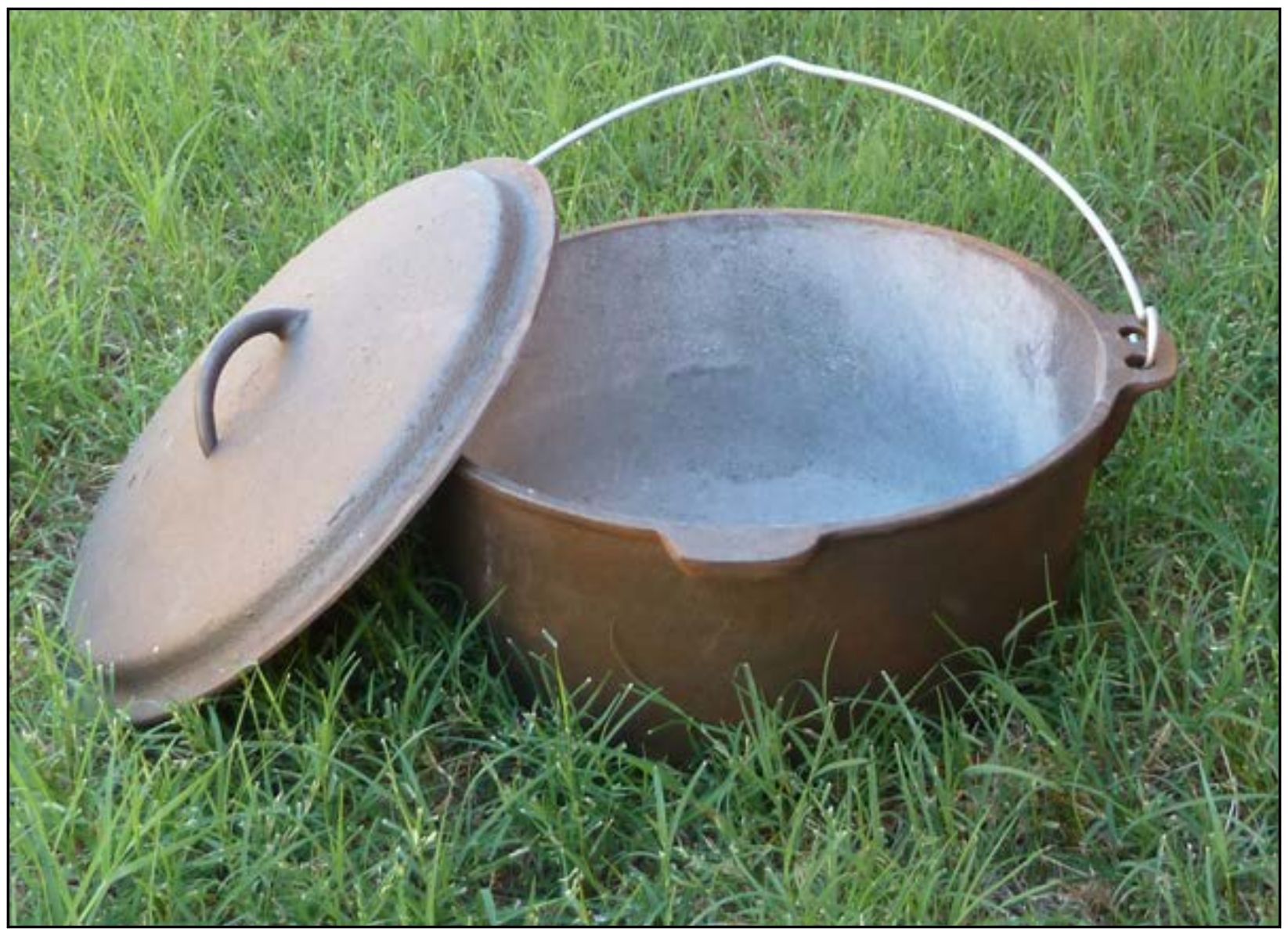

Figure 8. Cast iron Dutch oven used to transport coals for cedar ceremonies, Oklahoma, U.S.A. 2013. Photograph by Daniel C. Swan.

be ably met by the natural resources available in Osage County and the adjacent region. While several of these species had relevance and importance in the pre-peyote Osage Tribal Religion as recorded by Francis La Flesche $(1925: 220,1928: 89-90,1932: 21,226-27)$, current Osage Peyotists profess no continuity with respect to ceremonial usage over time. This is indicative of the strict enforcement of a prohibition on any continued practice of the Osage Tribal Religion following the acceptance of the Peyote Religion (Swan 1990:286-290, 1998:63).
This would suggest that the practical knowledge and ritual use of firewood among contemporary Osage Peyotists reflects a general peyote ethos with respect to ceremonial practice and interpretation.

Swan's research identified a core set of criteria (Table 2) employed by Osage Peyotists in their selection of firewood. As with all Peyotists practical considerations create a strong preference for firewood that produces a minimum of smoke, pops, and sparks. There is also the gen-

Table 2. Criteria employed by Osage Peyotists in the valuation of Peyote firewood, Oklahoma, U.S.A. Attributes of preferred species of firewood on a scale ranging from +++ (exceptional) to --- (unacceptable). Gradations are based on observations and discussions during the harvesting, processing and use of firewood by Osage Peyotists.

\begin{tabular}{|l|c|c|c|c|c|c|c|}
\hline Common Name & Heat & Light & Smoke & Sparks & Grain & Coals & Ashes \\
\hline Ash/ white Ash & +++ & ++ & - & -- & ++ & ++ & + \\
\hline Red oak & +++ & ++ & - & - & + & +++ & +++ \\
\hline Red bud & - & +++ & + & + & -- & -- & -- \\
\hline Red elm & ++ & ++ & + & - & ++ & ++ & ++ \\
\hline Cottonwood & + & ++ & + & + & ++ & + & - \\
\hline
\end{tabular}


eral need for the fire to produce light and heat appropriate to the season. Given the physical challenges of cutting and preparing peyote firewood, the ease of splitting, characterized by a fairly straight-grain, is also a primary consideration.

Despite the adoption of a general ceremonial structure and core theology of Peyotism communities have consistently accessed this religious form as the means to recharter and perpetuate localized elements from pre-Peyotism philosophies and cosmologies. The work of Jay Miller (1996:252-53) on the symbolic role of fire in Caddo ceremonial, social, and political dynamics is particularly pertinent to this discussion based on the Caddoan sources of Osage Big Moon Peyotism. Similar patterns are well evidenced among the Delaware in their transition from the Big House Religion to Big Moon Peyotism (Petrullo 1975:166-168).

Our examination of the ritual fire in Osage peyote ceremonialism reinforces the contention that the inter-tribal peyote ethos adopted by the Osage in their conversion to Big Moon Peyotism strongly reflects traditional Southeastern ceremonial patterns as interpreted and adapted among its Caddo and Delaware progenitors. The sweeping of the altar by the firemen displays a strong affinity for the same ritual act in the Delaware Big House Religion (Speck 1937:24), and the movement of coals from a sacred fire into multiple ritual and domestic settings (Howard 1984:131-34, Miller 1996:254, Speck 1909:114,120n) provide additional examples of relevance to the current discussion.

While the firewood itself may not perpetuate pre-peyote ceremonial practice and cosmology, the fire certainly is recognized and venerated by Osage Peyotists as an extension of Osage existence and a powerful force of both nature and man. In general the Osage Peyotists that Swan worked with celebrate fire as a gift from God, to provide the Osage people with light, heat, and the ability to cook their food. Swan's mentors emphasized that the ability to "make" fire is a critical element that distinguishes humans from other animals (Morrell 1994:045B).

Aesthetic considerations were found to be important criteria in the determination of preferred species for use as firewood in Osage Big Moon Peyotism. Leroy Myer's insightful discussion of aesthetics and Native American culture views the fire maintenance in Peyotism as a form of ritual performance that he terms "fire-sculpting" (2001:3132). The movement of coals and ashes from the ceremonial fires of Little Moon Peyotism into various designs (Figure 10) is well documented in the literature (Aberle 1991:134, La Barre 1989:77-78, Maroukis 2004:186, Radin 1970:368). Myers (2001:32) views this "fire sculpting" as representative of a pervasive "kinetic quality" in the ritual production of a physically separable art object.
A good fireman among the Osage is one who exhibits a general fluidity of motion, almost without thought, as he performs his ceremonial responsibilities. On several occasions Swan witnessed considerable discourse among Osage Peyotists regarding individuals who exhibited the ability to achieve this type of creative activity while facilitating the religious worship of the congregation. The motions and activity of the best of these individuals was often described as a form of religiously inspired dancing.

\section{Conclusion}

The ceremonial fire in Osage Big Moon Peyotism is a central element in the practical and ritual conduct of a religious service. The wooden frame church houses that cover Big Moon Peyote altars are large spaces to heat and light, placing a premium on firewood that satisfies both demands according to seasonal conditions and ritual demands. Coals are needed throughout the Osage Big Moon Peyote ceremony to continuously replenish the two coal mounds, important aesthetic features of the religious setting and a critical component in the transfer of spiritual blessings beyond the ceremonial setting into the larger Osage community. The fire is also viewed as a sacred entity and the visual and spiritual focus of the worshippers throughout the nightlong service.

Our research identified a core set of criteria used to identify species of firewood that mediate a broad set of practical, ritual, and aesthetic preferences. The undisputed favorite for this purpose among the Osage is red oak (Quercus shumardii Buckley) with slippery elm (UImus rubra Muhl.) and white ash (Fraxinus americana L.) acceptable substitutes. Fires from these woods produce abundant amounts of heat, light, and long-lasting coals with a minimum of smoke and sparks.

In Osage Big Moon Peyotism firewood comprises a set of plants that bind people and events together over both time and space, extending the social relations and sacred work of Peyotism into the larger Osage community. It is our hope that this brief discussion might encourage other researchers to broaden their frame of reference to incorporate dynamic aspects of human and plant interaction. This approach has benefitted our research on the ethnobotany of Osage Big Moon Peyotism by focusing our attention on both practical and ritual patterns of behavior and by introducing the concept of aesthetics in our analysis.

\section{Acknowledgments}

The authors wish to acknowledge the kind assistance and support of Osage community members, particularly the leadership and congregation of the Morrell family church in Hominy, Oklahoma, U.S.A. An early draft of this paper was presented at the 2011 meeting of the Plains Anthropological Society in Tucson, Arizona. The authors would 


\section{Swan \& Simons - An Ethnobotany of Firewood in Osage Big Moon Peyotism: 337 Practical knowledge, ritual participation, and aesthetic preference}

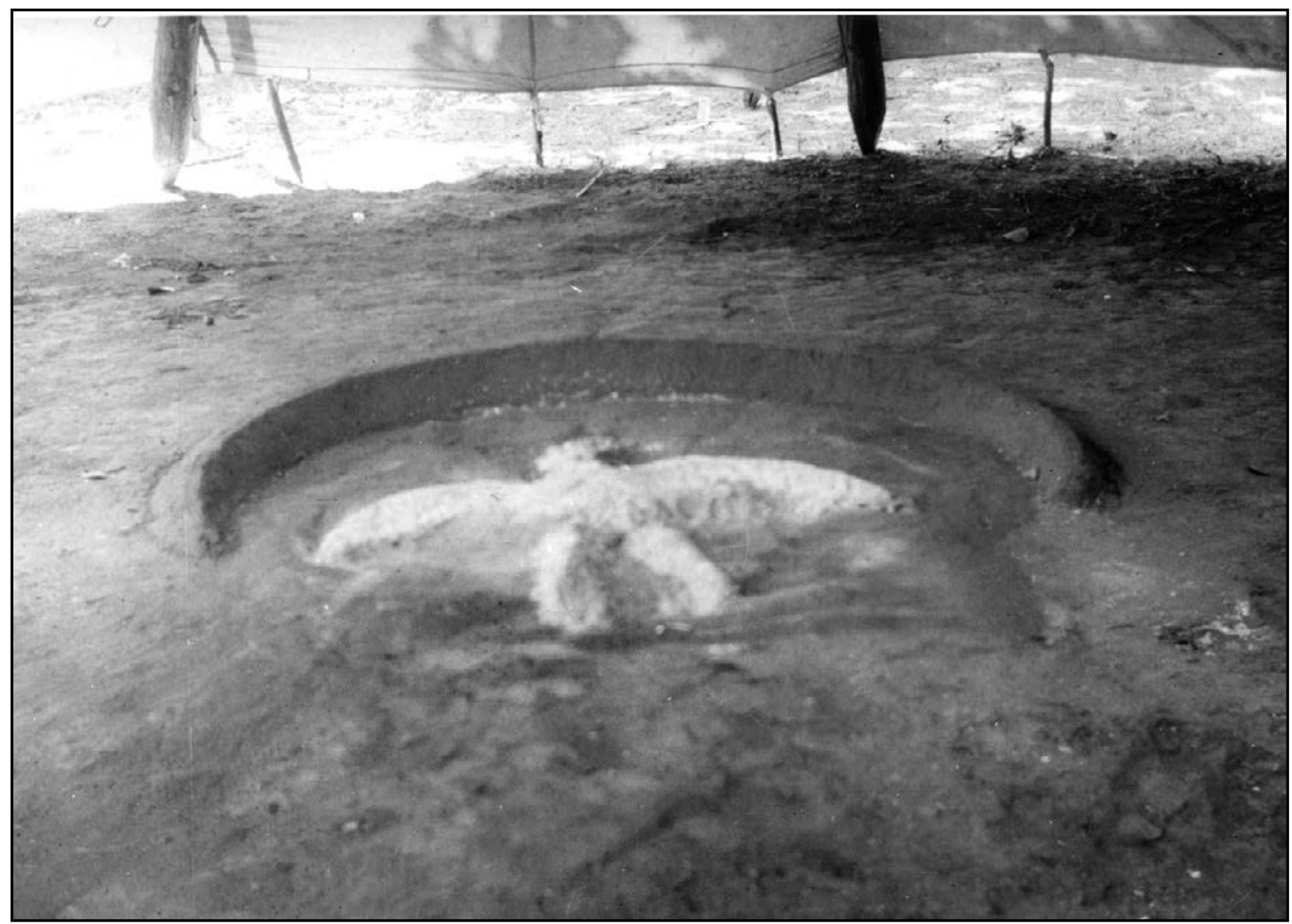

Figure 10. Ash Bird from a Little Moon Peyote service (post ceremony), Oklahoma, U.S.A. 1935. National Anthropological Archives, Smithsonian Institution, Washington, D.C, Neg.\#. 89-7099. Weston La Barre Collection - Box 13.

like to thank Jason Baird Jackson and Michael Paul Jordan for providing thoughtful comments on this paper prior to its submission for peer review. Our manuscript also benefits from the comments and suggestions provided by three anonymous reviewers.

\section{Literature Cited}

Aberle, D.F. 1991. The Peyote Religion Among the Navaho. Second edition. University of Oklahoma Press, Norman, Oklahoma, U.S.A.

Anderson, E.F. 1996. Peyote: The divine cactus. Second edition. University of Arizona Press, Tucson, Arizona, U.S.A.

Andre, A. 1995. Gwich'in Territorial Park Plant Report. Gwich'in Geographics LTD., Inuvik, Northwest Territories, Canada.

Andre, A. \& A. Fehr. 2010. Gwich'in Ethnobotany. Gwich'in Social and Cultural Institute and Aurora Research Institute, Northwest Territories, Canada.
Bailey, G.A. \& D.C. Swan. 2004. Osage Art. University of Washington Press, Seattle, Washington, U.S.A.

Bernard, H.R. 1911. Research Methods in Anthropology. Fifth edition. Altamira Press, Lanham, Maryland, U.S.A.

Biran, A., J. Abbot \& R. Mace. 2004. Families and firewood: A comparative analysis of the costs and benefits of children in firewood collection and use in two rural communities in Sub-Saharan Africa. Human Ecology 32(1):125. DOI: 10.1023/B:HUEC.0000015210.89170.4e

Chettri, N. \& E. Sharma. 2007. Firewood value assessment: A comparison on local preference and wood constituent properties of species from a trekking corridor, West Sikkim, India. Current Science 92(12)17441747. www.currentscience.ac.in/Downloads/article id $092 \_12 \quad 1744 \quad 1747 \quad 0 . p d f$

Chettri, N. \& E. Sharma. 2009. A scientific assessment of traditional knowledge on firewood and fodder values in Sikkim, India. Forest Ecology and Management 257:2073-2078. DOl:10.1016/j.foreco.2009.02.002 
Gilmore, M.R. 1991. Uses of Plants by the Indians of the Missouri River Region. Enlarged edition. University of $\mathrm{Ne}-$ braska Press, Lincoln, Nebraska, U.S.A.

Gottesfeld, L.M.J. 1994. Wet'suweten ethnobotany: Traditional plant uses. Journal of Ethnobiology 14 (2):185-210. http://ethnobiology.org/sites/default/files/pdfs/JoE/14-2/ Gottesfeld.pdf

Hill, G.A. 1971. Delaware ethnobotany. Oklahoma Anthropological Society Newsletter 19(3): 3-18.

Holloway, P.S. \& G. Alexander. 1990. Ethnobotany of the Fort Yukon Region, Alaska. Economic Botany 44(2): 214225. DOI:10.1007/BF02860487

Howard, J.H. 1981. Shawnee! The ceremonialism of a Native American Tribe and its cultural background. Ohio University Press, Athens, Ohio, U.S.A.

Howard, J.H. \& W. Lena. 1984. Oklahoma Seminoles Medicines, Magic, and Religion. University of Oklahoma Press, Norman, Oklahoma, U.S.A.

Jackson, J.B. 2003. Yuchi Ceremonial Life: Performance, meaning, and tradition in a contemporary American Indian community. University of Nebraska Press, Lincoln, Nebraska, U.S.A.

Jackson, J.B. 2005. East meets West: On stomp dance and powwow worlds in Oklahoma. Pp. 172-197 in Powwow. Edited by C. Ellis, E.L. Lassiter \& G. Dunham. University of Nebraska Press, Lincoln, Nebraska, U.S.A.

Jackson, J.B. 2013. Yuchi Folklore: Cultural expression in a Southeastern Native American community. University of Oklahoma Press, Norman, Oklahoma, U.S.A.

Johnson, L.M. 2008. Plants and habitats- A consideration of Dene ethnoecology in northwestern Canada. Botany 86:146-156. DOl:10.1139/B07-126

Jordan, J.A. 2008. Plains Apache Ethnobotany. University of Oklahoma Press, Norman, Oklahoma, U.S.A.

La Barre, W. 1989. The Peyote Cult. University of Oklahoma Press, Norman, Oklahoma, U.S.A.

La Flesche, F. 1925. Rite of vigil. Pp. 31-630 in $39^{\text {th }}$ Annual Report of the Bureau of American Ethnology. U.S. Government Printing Office, Washington, D.C., U.S.A.

La Flesche, F. 1928. The Osage tribe: Two versions of the child-naming rite. Pp. 23-164 in 43 ${ }^{\text {rd }}$ Annual Report of the Bureau of American Ethnology. U.S. Government Printing Office, Washington, D.C., U.S.A.
La Flesche, F. 1932. A Dictionary of the Osage Language. Bulletin 109, Bureau of American Ethnology. U.S. Government Printing Office, Washington D.C., U.S.A.

McAllester, D.P. 1949. Peyote Music. Viking Fund Publications in Anthropology, Number 13, New York, New York, U.S.A.

Maker, L., Sr. 1968. Oral history interview. Doris Duke Collection T- 344-1, December 12. Transcribed by Julia A. Jordan. Western History Collections, Norman, Oklahoma, U.S.A.

Maroukis, T.C. 2004. Peyote and the Yankton Sioux. University of Oklahoma Press, Norman, Oklahoma, U.S.A.

Metzger, D.G. \& G.E. Williams. 1966. Some procedures and results in the study of native categories: Tzeltal "firewood". American Anthropologist, New Series 68(2):389407. DOI:10.1525/aa.1966.68.2.02a00060

Meyer, L.N. 2001. In search of Native American aesthetics. Journal of Aesthetic Education 35 (4):25-46. www.jstor.org/stable/3333784

Miller, J. 1996. Changing moons: A history of Caddo religion. Plains Anthropologist 41(157):243-259.

Moerman, D.E. 1998. Native American Ethnobotany. Timber Press, Portland, Oregon, U.S.A.

Mooney, J. 1892. Eating the mescal. Augusta Chronicle January 24, 1892.

Mooney, J. 1896. The mescal plant and ceremony. Therapeutic Gazette, Third series 12:7-11.

Mooney, J. 1897. The Kiowa peyote rite. Der Urquell 1897:329-333.

Moore, J.H. 1987. The Cheyenne Nation. University of Nebraska Press, Lincoln, Nebraska, U.S.A.

Morehart, C.T., D.L. Lentz \& K. Prufer. 2005. Wood of the gods: The ritual use of pine (Pinus spp.) by the ancient lowland Maya. Latin American Antiquity 16(3):255-274. www.jstor.org/stable/30042493

Morrell, P. 1986. Oral history interview. DCS-012-00-ACA/B. July 29, 1986, Hominy, Oklahoma, U.S.A.

Morrell, P. 1994. Oral history interview, DCS-044-00AC-A; DCS-045-00-AC-A/B. November 30, 1994, Tulsa, Oklahoma, U.S.A.

Onion, D.K. 1964. Corn in the culture of the Mohawk Iroquois. Economic Botany 18(1):60-66. 


\section{Swan \& Simons - An Ethnobotany of Firewood in Osage Big Moon Peyotism: 339 Practical knowledge, ritual participation, and aesthetic preference}

Noyes, D. 2003. Fire in the Plaça: Catalan festival politics after Franco. University of Pennsylvania Press, Philadelphia, Pennsylvania, U.S.A.

Oklahoma Biological Survey. 2013. Oklahoma Vascular Plants Database. www.oklahomaplantdatabase.org/

Pennacchio, M., L. Jefferson \& K. Havens. 2010. Uses and Abuses of Plant Derived Smoke. Oxford University Press, New York, New York, U.S.A.

Petrullo, V. 1975. The Diabolic Root: A study of peyotism, the new Indian religion among the Delawares. Octagon Press, New York, New York, U.S.A.

Quintero, C. 2009. Osage Dictionary. University of Oklahoma Press, Norman, Oklahoma, U.S.A.

Radin, P. 1970. The Winnebago Tribe. Bison Books. University of Nebraska Press, Lincoln, Nebraska, U.S.A.

Ramos, M.A., P. Muniz de Medeiros, A.L. Santos de Almeida, A.L.P. Feliciano \& U.P. de Albuquerque. 2008. Can wood quality justify local preferences for firewood in an area of caatinga (dryland) vegetation? Biomass and Bioenergy 32:503-509. DOI:10.1016/j.biombioe.2007.11.010

Schultes, R.E. 1937. Peyote and plants used in the peyote ceremony. Botanical Museum Leaflets, Harvard University 4(8):129-152. www.biodiversitylibrary.org/ item/31893\#page/6/mode/1up

Slotkin, J.S. 1952. Menominee peyotism. Transactions of the American Philosophical Society 42(4):565-680.

Slotkin, J.S. 1956. The Peyote Religion: A study in Indian White relations. Free Press, New York, New York, U.S.A.

Speck, F. 1909. Ethnology of the Yuchi Indians. Anthropological Publications of the University Museum, University of Pennsylvania 1(1):1-154.

Speck, F. 1933. Notes on the life of John Wilson, the revealer of peyote, as recalled by his nephew, George Anderson. The General Magazine and Historical Quarterly 35:539-556.

Speck, F. 1937. Oklahoma Delaware ceremonies, feasts and dances. Memoirs of the American Philosophical Society $7: 1-161$.
Stern, A.C. \& A.M. Squires. 1984. Firewood conservation. Science, New Series 226(4680):1250-1252.

Stewart, O. 1987. The Peyote Religion: A history. University of Oklahoma Press, Norman, Oklahoma, U.S.A.

Swan, D.C. 1990. West Moon-East Moon: An ethnohistory of the peyote religion among the Osage Indians. Ph.D. dissertation. University of Oklahoma, Norman, Oklahoma, U.S.A.

Swan, D.C. 1998. Early Osage peyotism. Plains Anthropologist 43(163):51-71.

Swan, D.C. 1999. Peyote Religious Art: Symbols of faith and belief. University Press of Mississippi, Jackson, Mississippi, U.S.A.

Taylor, M.J. 2006. Biomass in the borderlands: Charcoal and firewood production in Sonoran Ejidos. Journal of the Southwest 48(1):63-90.

USDA. 2009. Plants Database. National Resource Conservation Service. http://plants.usda.gov/core/ profile?symbol=NELU

U.S. Congress, House Committee on Indian Affairs. 1918. Hearings on HR 2614, part 1, February 21-25; part 2, March 23. $67^{\text {th }}$ Congress, Second Session. US Government Printing Office, Washington, D.C., U.S.A.

van Kempen, L., R. Muradiana, C. Sandóvalb \& J.-P. Castañedab. 2009. Too poor to be green consumers? A field experiment on revealed preference for firewood in rural Guatemala. Ecological Economics 68(7):2160-2167. DOl:10.1016/j.ecolecon.2009.02.014

Vestal, P.A. \& R.E. Schultes. 1939. The Economic Botany of the Kiowa Indians as it Relates to the History of the Tribe. Botanical Museum, Harvard University, Cambridge, Massachusetts, U.S.A.

Wishart, R.P. 2004. Living "On the Land:" Teetl'it Gwich'in in Perspectives on Continuities. Ph.D. dissertation. Department of Anthropology, University of Alberta, Edmonton, Alberta, Canada. 